\title{
PERSEPSI SISWA SMP UNISMUH MAKASSAR TERHADAP TOLERANSI ANTARUMAT BERAGAMA
}

\author{
INDAH RAHAYU \\ Program Pascasarjana \\ Universitas Islam Negeri Alauddin Makassar \\ E-mail: indah_3009198@yahoo.co.id
}

\begin{abstract}
Tolerance is a human attitude as a religious people and has the confidence to respect and appreciate the religious views of other human beings. To realize tolerant attitude among educated people needed a good understanding of religion as well, and required the role of parents, teachers, and the role of preachers in delivering advice and da'wah in accordance with religious texts contextually. So that the community, especially the students can run their religion properly, peace and tolerance. If tolerance is seen from the students' understanding, it will be known how important this tolerance is reflected in the life of the students as religious people, so that Islamic tradition will substantially manifest itself against tolerant views. Because the core of tolerance is respect for other religious people and not discriminatory to certain people as an effort to awareness of equality of rights and values of Pancasila.
\end{abstract}

\begin{abstract}
Abstrak
Penelitian ini bertujuan untuk mengetahui dan menggambarkan bagaimana Persepsi Siswa Siswa SMP Unismuh Makassar terhadap Toleransi Antarumat Beragama. Jenis penelitian adalah deskriptif kualitatif dengan pendekatan penelitian yang digunakan adalah fenomenologis-teologis. Adapun sumber data penelitian ini adalah Siswa SMP Unismuh Makassar. Metode pengumpulan data yang digunakan adalah observasi, wawancara lisan (dialog) dan tulisan, dokumentasi, dan penelusuran referensi. Kemudian teknik pengolahan dan analisis data dilakukan melalui beberapa tahapan, yaitu reduksi data, penyajian data, menjelaskan, menggambarkan, dan penarikan kesimpulan. Toleransi merupakan sikap manusia sebagai umat yang beragama dan mempunyai keyakinan untuk menghormati dan menghargai pandangan keagamaan manusia yang beragama lain. Untuk mewujudkan sikap toleran di kalangan terdidik diperlukan pemahaman agama yang baik pula, dan diperlukan peran orang tua, guru, serta peran mubaligh dalam menyampaikan nasihat dan dakwah yang sesuai dengan teks-teks keagamaan secara kontekstual. Sehingga masyarakat, khususnya para anak didik dapat menjalankan agamanya secara benar, damai, dan toleran. Apabila toleransi ditinjau dari pemahaman siswa, maka akan diketahui seberapa penting toleransi ini direfleksikan dalam kehidupan siswa sebagai umat yang beragama, sehingga tradisi Islam secara substansi akan sendirinya termanifestasi terhadap pandangan-pandangan toleran. Karena inti dari toleransi yakni rasa hormat terhadap umat beragama lain serta tidak diskriminatif pada umat tertentu sebagai upaya kesadaran persamaan hak dan nilai-nilai pancasila.
\end{abstract}

Keywords:

Persepsi, Siswa, Toleransi, Umat, Agama 


\section{PENDAHULUAN}

\section{A. Latar Belakang}

Toleransi pada dasarnya adalah upaya untuk menahan diri agar konflik dapat diredam atau dihindari. ${ }^{1}$ Namun, fenomena keagamaan umat dewasa ini cenderung diwarnai konflik dan kekerasan. Semua itu dipicu oleh sikap saling curiga dan saling benci antarpemeluk agama dan antarmazhab dalam suatu agama. Pertumpahan darah pun tidak terhindarkan. Masing-masing umat beragama merasa benar menempuh langkah seperti itu dianggap sebagai bagian dari ajaran agamanya. Menghabisi pemeluk agama lain, dalm konteks tertentu dianggap sah menurut ajaran agamanya. Inilah wajah buram bentuk keberagamaan yang ditopang oleh eksklusivisme. ${ }^{2}$ Secara fundamental, sikap eksklusif terjadi karena adanya kesempitan wawasan dan kejumudan dalam memahami agama, dan yang terjadi saat ini ekslusivisme dan ektremisme sudah mewabah ke dunia pendidikan.

Pluralitas sebagai eksistensial sejak dahulu. Karena eksistensialnya kini ia terbawa ke dunia pendidikan, dan tak jarang karena pluralitas keberagamaan maka toleransi perlu hadir di tengah-tengah peserta didik agar para peserta didik dapat saling menghargai dan menghormati umat pemeluk agama lain. Namun, yang terjadi saat ini semakin sempitnya bidang ilmu pengetahuan yang menafikan pemikiran dan ilmu-ilmu alam, kurikulum pun dibatasi pada ilmu agama murni. ${ }^{3}$ Saat ini di sekolah-sekolah pesantren atau semi pesantren lebih mendorong siswa kepada hafalan ketimbang pemahaman, ini yang membuat kemerosotan bagi siswa untuk dapat menggeluti soalsoal pelik seputar aspek ilmu-ilmu keagamaan yang masih baru, dan implikasinya lahirlah sikap intoleran di kalangan pendidik dan peserta didik.

Di sekolah semi pesantren tersebut, tidak secara komprehensif menghendaki pendidikannya harus berpusat pada buku pelajaran saja, melainkan juga wawasan para siswa lebih ditekankan pada pelajaran hafalan al-qur'an dan hadis. Ungkapan para siswa dan guru-guru di sekolah tersebut menyatakan bahwa sebelum belajar para siswa membaca al-Qur'an dan pada akhir pelajaran menghafal surah-surah secara bersama yang diberikan oleh guru mereka. Selanjutnya di mata pelajaran lain dikhususkan pada penghafalan bagi siswa-siswi di waktu-waktu tertentu. Peneliti mengamati metode ini hanya difokuskan pada penghafalan, soal penjelasan arti dan makna dari surah-surah yang mereka hafal tidak begitu dipentingkan (tekstualis). Secara substansial guru bertugas mendisiplikan cara pandang dan pemahaman siswa-siswi guna mencari kebenaran demi karena cinta pada kebenaran, karena dengan cinta semangat toleransi akan selalu hidup, dan sikap intoleran akan termajinalkan.

\footnotetext{
${ }^{1}$ Syarif Hidayatullah, Islam Isme-Isme, Aliran dan Paham Islam di Indonesia (Cet. I; Yogyakarta: Pustaka Pelajar, 2010), h. 113.

${ }^{2}$ Tim Penulis Alumni Timur Tengah, Konstruksi Islam Moderat, h. 37.

${ }^{3}$ Fazlur Rahman, Islam, Sejarah Pemikiran dan Peradaban, terj. M. Irsyad Rafsadie (Cet. I; Bandung: PT. Mizan Pustaka, 2016), h. 285.
} 
Dalam mewujudkan toleransi yang baik, teks-teks agama tidak harus dipahami secara tekstual, karena atas dasar pemahaman itu seringkali umat bersikap intoleran maupun ekstrem. Sebab hal tersebut berawal dari para pendidik yang memahami agama atas persepsi skriptualis, dan tak jarang dapat berpengaruh kepada siswa atau peserta didik.

Menurut Fazlur Rahman, pendidikan harus menggunakan epistemologi tersendiri yang disebut sebagai epistemologi komprehensif. Hal tersebut berdasarkan asumsi bahwa hakekat pendidikan Islam adalah proses pengembangan seluruh potensi manusia yang menghargai pluralitas dan heterogenitas sebagai konsekuensi keragaman budaya, etnis, suku, dan aliran (agama). Sehingga sumber pengetahuan adalah teks-teks kitab suci, realitas alam, fenomena sosial, dan intuisi, indrawi, dan akal (rasio). Sehingga peringkat umum yang harus dilakukan gerakan memperhitungkan kondisikondisi sosial sekarang. ${ }^{4}$

Dibutuhkan kalangan terdidik dari kesadaran penuh untuk menanamkan nilainilai toleransi kepada siswa, agar siswa dapat berperilaku secara toleran dan inklusif tanpa terdapat sikap-sikap yang berpotensi mengarah pada intoleransi. Pertanyaan kemudian muncul, apakah dari kalangan terdidik sendiri telah terdapat sikap-sikap yang berpotensi mendukung terciptanya toleransi antarumat beragama ataukah justru sebaliknya, sikap-sikap yang diperlihatkan berpotensi untuk menciptakan intoleransi antarumat beragama di lingkungan sekolah dan lingkungan masyarakat secara komprehensif.

\section{B. Rumusan Masalah}

Adapun rumusan masalah yang akan dibahas dalam tulisan ini adalah sebagai berikut:

1. Bagaimana pemahaman siswa SMP Unismuh Makassar terhadap wacana toleransi antarumat beragama?

2. Bagaimana sikap toleransi siswa tersebut terhadap non-Muslim?

3. Faktor-faktor yang memengaruhi persepsi siswa terhadap konsep toleransi antarumat beragama?

4. Bagaimana upaya optimalisasi rekonsrtuksi persepsi siswa terhadap toleransi antarumat beragama?

\section{PEMBAHASAN}

\section{A. Tinjauan Definisi tentang Persepsi}

Persepsi diartikan sebagai tanggapan (penerimaan) langsung dari sesuatu, proses seseorang mengetahui beberapa hal melalui penginderaannya. Persepsi pada hakikatnya adalah proses kognitif yang dialami oleh setiap orang didalam memahami

\footnotetext{
${ }^{4}$ Abd. Rachman Assegaf, Aliran Pemikiran Pendidikan Islam, Hadharah Keilmuan Tokoh Klasik Sampai Modern (Cet. I, Jakarta: PT. RajaGrafindo Persada, 2013), h. 227.
} 
informasi tentang lingkungannya, lewat penglihatan, pendengaran, penghayatan, perasaan dan penciuman. Dalam psikologi komunikasi, bagaimana persepsi orang terhadap kita, atau bagaimana persepsi kita tentang orang lain dinamakansebagai sistem komunikasi interpersonal. ${ }^{5}$ Sedangkan, persepsi dalam Kamus Besar Bahasa Indonesia (KBBI) adalah tanggapan atau penerimaan langsung dari sesuatu. ${ }^{6}$

Dalam persepsi terdapat dua kemampuan gerak yaitu gerakan aktif dan gerakan impulsif. Gerakan aktif disalurkan melalui saraf dan otot untuk mengerutkan atau mengendorkan otot-otot dan urat daging sehingga bisa mendekat atau menjauhi sebuah titik beranjak. Gerakan impulsif ada dua macam, yaitu ada yang didasarkan pada keinginan (desire), dan ada yang muncul dari rasa marah. Yang pertama membuat gerakan yang menarik seseorang lebih dekat kepada benda-benda yang dibayangkan perlu, bermanfaat dan menimbulkan kenikmatan. Yang kedua membuat gerakan yang bisa menolak dan menghindari hal-hal yang dipandang berbahaya dan merusak. Kemampuan kedua yakni kemampuan perseptif, terbagi dalam dua sub-bagian, yakni indra lahir (external senses) dan indra batin (internal senses). Indra lahir dikenal dengan nama pancaindra, yaitu terdiri dari penglihatan, pendengaran, penciuman, rasa dan sentuhan. Sedangkan indra batin terdiri dari lima daya (faculties), yaitu:

1. Indra bersama (common sense/al-hissāl-musytārakah). Daya ini berfungsi untuk menerima, mengatur dan mengkoordinir bentuk-bentuk dari indra bersama ini menyusun segala informasi yang masuk sehingga dengan benar ia mencerminkan benda-benda fisik dunia lahiriah. Tanpa mekanisme seperti ini, seseorang akan menerima bentuk-bentuk yang diberikan oleh masing-masing kelima indra tersebut secara sendiri-sendiri.

2. Imajinasi retentif (khayal) atau disebut juga representasi (mushawwirah).. meskipun indra bersama menerima dan menyusun bentuk-bentuk indrawi, tetapi ia tidak menyimpannya. Tugas ini diambil oleh imajinasi retentif, yang fungsinya adalah melestarikan informasi yang diterima oleh indra bersama untuk kemudian disalurkan ke daya-daya yang lainnya. Dengan begitu maka imajinasi retentif ini memungkinkan kita untuk mengingat kembali gambar (image/citra) dari sebuah benda dalam pikiran kita, sekalipun benda tersebut sudah tidak lagi secara langsung berada di hadapan kita.

3. Imajinasi kompositif (mutakhayyilāh), kalau daya ini berada pada hewan, dan disebut daya kogitatif kalau berada pada manusia. Daya ini bertindak terhadap gambar-gambar indrawai yang dihimpun dalam imajinasi retentif. Tugasnya adalah untuk memisahkan atau menggabungkan kembali gambar-gambar tersebut dengan beberapa cara. Karena itu kita dapat

\footnotetext{
${ }^{5}$ Achmad Mubarok, Psikologi Dakwah (Jakarta: Pustaka Firdaus, 2001), h. 128

${ }^{6}$ Kamus Besar Bahasa Indonesia, Kamus versi online, https://kbbi.web.id/persepsi.html, diakses pada 12 Agustus 2017 pukul 21.20.
} 
membayankan/mengkhayalkan makhluk-makhluk yang tidak pernah ada, seperti manusia terbnag atau gunungn zamrud hijau.

4. Daya estimasi (wahm). Estimasi ini menagkap "makna" dan "tujuan" yang ada pada benda-benda indrawi ketimbang sekadar bentuk lahiriah mereka. Daya ini mengerti, misalnya, bahwa berunag harus dijauhi, sedangkan anak kecil harus diperlakukan lembut dan penuh kasih sayang. Estimasi ini merupakan daya yang mengatur dalam jiwa hewan . ia mengkoordinir kegiatan-kegiatan dari indra-indara batin lainnya sehingga mengarahkan nafsu hewani tersebut untuk bertinda. Pada diri manusia, day estimasi ini melakukan upaya tambahan untuk menilai kenyataan empiris dari bentuk-bentuk yang dipisah-pisah atau digabung kembali oleh imajinasi kompositif, sehingga kita bisa menilai mana ynag bisa dipercaya dan mana yang bersifat fantastik.

5. Memori atau daya preservative (khafidläh) atau rekolektif (dzakirah, mudzakirah). Memori (ingatan) merupakan gudang dari persepsi daya estimasi. Funsinya adalah untuk melestarikan "makna" atau "maksud" yang terdapat dalam estimasi, seperti halnya pelestarian yang dilakukan imajinasi retentigf terhadap gambar atau bentuk yang ada dalam indra bersama. Memori juga disebut recollection (tadzakkur) karena disamping untuk menyimpan informasi, ia juga bisa memulihkannya kembali untuk daya estimasi pada hewan dan untuk estimasi dari intelek pada diri manusia. ${ }^{7}$

Daya jiwa yang ketiga adalah rasional atau insaniyah. Jiwa rasional ini mempunyai dua aspek, yaitu: akal praktis dan akal teoretis. Akal praktis berbagi fungsi dengan jiwa nabati dan hewani. Tetapi ia mengungguli keduanya karena ia bisa mengambil premis-premis rasional yang berguna dilihat dari pandangan-pandangan etik dan politik praktis (bahwa berbohong dan tirani itu jahat, tetapi menyatakan kebenaran dan bertindak adiliyu baik). Fungsi utama akal praktis adalah menggunakan indikasi untuk membimbing, mengatur dan menguasai daya-daya atau nafsu-nafsu dari jiwa-jiwa yang lebh rendah. Kalau berhasil, akal praktis dapat merangsang tingkah laku etis yang baik. Tetapi kalau jiwa nabati dan hewani yang menguasai akal praktis, maka tatanan alamiah jiwa jadi terbalik, dan moral yang buruk akan muncul. ${ }^{8}$

Bagi hampir setiap orang, sangat mudah untuk melakukan aktivitas mendengar, melihat, mencium, menyentuh, dan merasakan. Namun, informasi yang datang dari organ-organ indera perlu terlebih dahulu diorganisasikan dan diinterpretasikan sebelum dapat dimengerti, dan proses ini dinamakan persepsi. Jadi, dapat disimpulkan, bahwa persepsi merupakan komponen pengamatan yang di dalam proses ini melibatkan pemahaman dan penginterpretasian sekaligus.

${ }^{7}$ Abd. Rachman Assegaf, Aliran Pemikiran Pendidikan Islam, Hadharah Keilmuan Klasik Sampai Modern, (Jakarta: Raja Grafindo Persada, 2013), h. 89-90.

${ }^{8}$ Abd. Rachman Assegaf, Aliran Pemikiran Pendidikan Islam, Hadharah Keilmuan Klasik Sampai Modern, h. 90-91. 


\section{B. Tinjauan Tentang Siswa}

Pengertian Siswa/Murid/Peserta Didik. Di dalam KKBI, Pengertian "murid" berarti orang (anak yang sedang berguru, belajar, bersekolah). ${ }^{9}$ Sedangkan menurut Shafique Ali Khan, pengertian siswa adalah orang ynag datang ke suatu lembaga untuk memperoleh atau mempelajari beberapa tipe pendidikan. Seorang pelajar adalah orang yang mempelajari ilmu pengetahuan berapa pun usianya, dari mana pun, siapa pun, dalam bentuk apa pun, dengan biaya apa pun untuk meningkatkan intelek dan moralnya dalam rangka mengembangkan dan membersihkan jiwanya dan mengikuti jalan kebaikan. $^{10}$

Siswa sebagai subjek belajar memiliki karakteristik yang berbeda-beda baik dari aspek psikologis maupun minat, bakat, kebiasaan, motivasi, situasi sosial, lingkungan keluarga, dan harapan masa depannya. ${ }^{11}$ Menurut pasal 1 ayat 4 UU RI No. 20 Tahun 2003 tentang system pendidikan nasional, peserta didik adalah anggota masyarakat yang berusaha mengembangkan dirinya melalui proses pendidikan pada jalur, jenjang, dan jenis pendidikan tertentu. ${ }^{12}$

Dari pengertian di atas dapat disimpulkan bahwa, siswa adalah peserta didik yang bertugas dan berkewajiban menjaga etika dalam rangka terwujudnya proses dan keberhasilan pendidikan baik di ligkungan sekolah, keluarga, dan masyarakat.

\section{Tinjauan Tentang Toleransi Antarumat Beragama \\ 1. Pengertian Toleransi}

Secara etimologi berasal dari kata tolerance(dalam bahasa Inggris) yang berarti sikap membiarkan, mengakui dan menghormati keyakinan orang lain tanpa memerlukan persetujuan. Di dalam bahasa Arab menterjemahkan dengan tasāmuh, berarti saling mengizinkan, saling memudahkan. ${ }^{13}$ Tasamuh terderivasi dari kata alsimāh dan al-samāhah yang berarti kemurahan, kasih sayang, pengampunan, dan perdamaian. Jika dikaitkan dengan interreligius, maka toleransi dapat diartikan sebagai kemurahan, kasih sayang, pengampunan, dan perdamaian Islam kepada pemeluk agama lain. ${ }^{14}$ Toleransi diartikan sebagai pemberian kebebasan kepada sesama manusia atau kepada sesama warga masyarakat untuk menjalankan keyakinannya atau mengatur hidupnya dan menentukan nasibnya masing-masing, selama di dalam menjalankan dan

\footnotetext{
${ }^{9}$ Departemen Pendidikan dan Kebudayaan, Kamus Besar Bahasa Indonesia (Jakarta: Balai Pustaka, 1990), h. 601.

${ }^{10}$ Shafique Ali Khan, Filsafat Pendidikan Al-Ghazali (Bandung: Pustaka Setia, 2005), h. 62

${ }^{11}$ Pupuh Faturrohman dan M. Sobry Sutikno, Strategi Belajar Mengajar, (Bandung: PT. Refika Aditama, 2007), cet. 1 h. 55.

${ }^{12}$ UU Sistem Pendidikan Nasional, (UU RI. No. 20 Tahun 2003) (Cet. IV, Jakarta: Sinar Grafika, 2011), h. 3.

${ }^{13}$ Said Agil H. Al-Munawar, Fiqih Hubungan Antar Agama (Jakarta: Ciputat Press),h. 13.

${ }^{14}$ Irwan Masduqi, Berislam Secara Toleran, Teologi Kerukunan Umat Beragama(Cet. I, PT. Mizan Pustaka, 2012), h. 229-230.
} 
menentukan sikapnya itu tidak bertentangan dengan syarat-syarat atas terciptanya ketertiban dan perdamaian dalam masyarakat. ${ }^{15}$

Dari dua pengertian di atas menurut analisa peneliti, toleransi secara etimologi adalah sikap saling mengizinkan dan menghormati keyakinan orang lain, penerimaan, dan apresiasi terhadap keragaman budaya tanpa memerlukan persetujuan. Toleransi harmoni dalam perbedaan, keragaman, yang membuat perdamaian menjadi mungkin.

\section{Pengertian Umat}

Menurut Ar-Raghib al-Ashfahani jika mengacu pada terminologi al-Qur'an, maka istilah umat secara kebahasan memiliki beberapa makna yang berbeda-beda: pertama, umat adalah jama'ah yang dihimpun oleh suatu urusan, yakni satu agama, baik hal itu terjadi karena kondisi maupun karena diusahakan. Kedua, umat berarti macam atau jenis tertentu. Ketiga, umat yang berarti golongan yang satu 'Manusia adalah umat yang satu..." (QS. al-Baqārah: 213). Keempat, makna umat berarti jama'ah. ${ }^{16}$ Oleh karena itu, ar-Raghib al-Ashfahani kemudian mendefinisikan istilah umat sebagai seluruh kelompok manusia yang disatukan oleh suatu hal, baik agama yang satu maupun tempat yang satu. Faktor yang menyatukan mereka adalah takdir atau pilihan sendiri. Dengan kata lain, istilah umat mengandung pengertian sekelompok manusia yang disatukan oleh suatu hal yang membedakan dengan kelompok-kelompok lainnya. Fakta yang menyatukan dapat karena ciptaan ilahi seperti tabiat, sifat dan bawaan, atau karena pilihan manusia sendiri yang bersifat sintesis. ${ }^{17}$

Selanjutnya hal yang sama dikemukakan oleh Ali Syari'ati, menurutnya kata umat berasal dari bahasa Arab umun, yaümun, yang berarti "menuju, berniat, bermaksud, dan bertujuan". Kata ini juga mengandung pengertian "gerakan (intention), dan ketetapan kesadaran, serta jalan yang jelas. Berangkat dari akar ini, Syari'ati merumuskan kata umat dengan sekelompok masyarakat yang terdiri atas sejumlah inidividu yang memiliki dasar kepercayaan dan tujuan yang sama, bahu membahu dalam suasana kedamaian bergerak untuk mencapai tujuan yang sama (a society in which a number of individuals, possessing a common faith and goal, come together in harmony with the intention of advancing and moving toward their common goal). ${ }^{18}$

Menurut Thabāthabā'i sebagaimana dikutip oleh Muthahāri, menyatakan bahwa kesatuan dalam masyarakat Islam disebut dengan ummah, sebuah konsep yang terdapat dalam al-Qur'an, yang mengandung pengertian bahwa masyarakat harus

\footnotetext{
${ }^{15}$ Umar Hasyim, Toleransi dan Kemerdekaan Beragama dalam Islam Sebagai Dasar Menuju Dialog dan Kerukunan Antar Agama (Surabaya: PT. Bina Ilmu, 1979), h. 22.

${ }^{16}$ Munir Che Anam, Muhammad SAW \& Karl Marx (Tentang Masyarakat Tanpa Kelas), (Cet. I; Yogyakarta: Pustaka Pelajar, 2008), h. 22-23. 23.

${ }^{17}$ Munir Che Anam, Muhammad SAW \& Karl Marx (Tentang Masyarakat Tanpa Kelas), h. $23-24$

${ }^{18}$ Munir Che Anam, Muhammad SAW \& Karl Marx (Tentang Masyarakat Tanpa Kelas), h.
} 
memiliki gagasan sejarah bersama, tujuan bersama, perbuatan, kesadaran pengertian, perasaan, dan perilaku bersama. Lebih lanjut, Thabāthabā'i menjelaskan bahwa alQur'an melihat kehidupan sebagai suatu keberadaan bersama yang bukan kiasan atau perlambang, melainkan kenyataan bahwa kehidupan ini adalah berkaitan dengan ummah (bangsa) dan bukan dengan individu-individu. Bahkan, bukan hanya individu saja yang akan ditentukan catatan perbuatannya, namun masyarakat juga harus mempertanggungjawabkan kebebasan kehendak dan tindakannya sebagai sebuah bangsa. Hal ini karena setiap bangs ${ }^{19}$ a berjalan berdasarkan kesadaran norma dan cara berpikirnya sendiri. Sehingga keingkaran bersama yang menjadi tekad bersama pat ut dihukum secara bersama pula.

Lebih jauh memahami makna bahasa dari "umat", tampaknya penjelasan yang diketengahkan oleh M. Quraish Shihab sedikit banyak akan membantu. Menurutnya, umat itu terambil dari kata يؤمّ-أمّ ('amma-yaūmmu) yang berarti menuju, menumpu dan meneladani, dari akar kata yang sama kemudian lahir kata um berarti "ibu" dan imam yang artinya "pemimipin", karena keduanya menjadi teladan, tumpuan, dan harapan. ${ }^{20}$ Kata ummat dalam bentuk mufrad (tunggal) disebut sebanyak lima puluh dua kali di dalam Al-Qur'an. ${ }^{21}$ Kata umat dalam QS. al-Baqarah/2: 213 sebagai berikut:

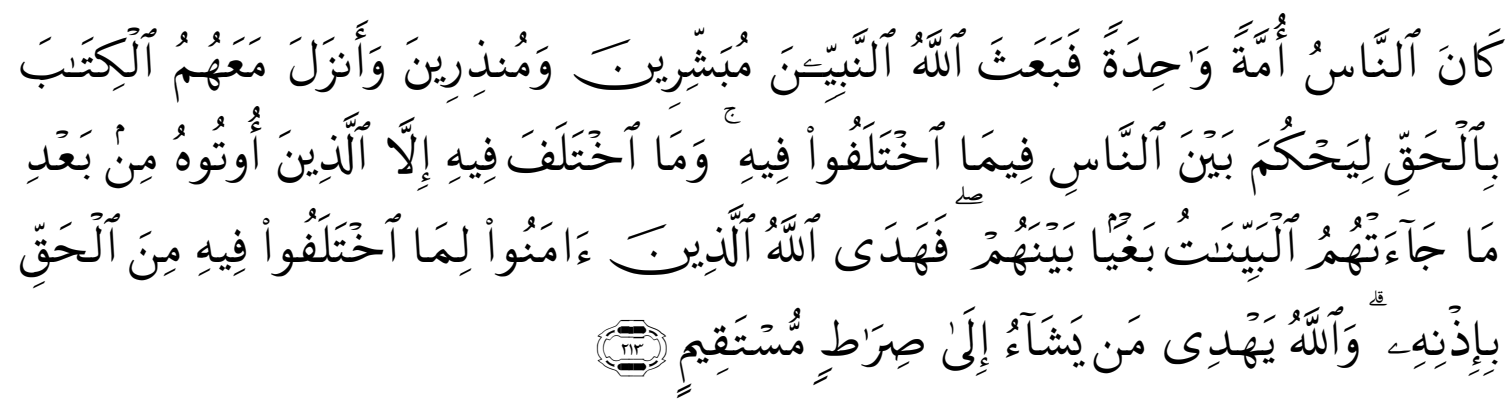

Terjemahnya:

Manusia itu adalah umat yang satu, (setelah timbul perselisihan), maka Allah mengutus para Nabi, sebagai pemberi peringatan, dan Allah menurunkan bersama mereka kitab yang benar, untuk memberi keputusan di antara manusia tentang perkara yang mereka perselisihkan. Tidaklah berselisih tentang kitab itu melainkan orang yang telah didatangkan kepada mereka kitab, yaitu setelah datang kepada mereka keterangan-keterangan yang nyata, karena dengki antara mereka sendiri. Maka Allah memberi petunjuk orang-orang yang beriman kepada kebenaran tentang hal yang mereka perselisihkan itu dengan kehendakNya. Dan Allah selalu memberi petunjuk orang yang dikehendaki-Nya kepada jalan yang lurus. $^{22}$

${ }^{19}$ Munir Che Anam, Muhammad SAW \& Karl Marx (Tentang Masyarakat Tanpa Kelas), h.

27.

\footnotetext{
${ }^{20}$ M. Quraish Shihab, Wawasan Al-Quran, h. 325.

${ }^{21}$ M. Quraish Shihab, Wawasan Al-Quran, h. 325.

${ }^{22}$ Kementerian Agama, Al-Qur'an dan Terjemahnya, h. 33.
} 


\section{Pengertian Agama}

Setidaknya ada tiga kata yang sering diterjemahkan secara berdekatan menjadi agama, yaitu millah, din, dan syari'ah. Makna dasar dari millah, din, dan syari'ah menurut Thabathaba'i adalah al-thariqah ("jalan"). Akan tetapi, dalam penggunaannya, ketiga kata tersebut memiliki makna yang berbeda. Berikut adalah uraian mengenai ketiganya.

\section{a. Makna Millah}

Kata millah merupakan bentuk tunggal dari kata milal, yang berarti menuliskan catatan atau mengimlakan, yakni membacakan kepada orang lain agar ditulis olehnya yang lazim disebut mendikte bacaan. Makna seperti ini sebagaimana terdapat dalam QS. al-Baqarah [2]: 282 menjelaskan transaksi dagang dan sosial secara umum yang diperintahkan untuk dibuat tercatat atau tertulis. Menurut Djaka Soetapa, kata millah diambil dari bahasa Aram yang dalam al-Qur'an berarti din. Menurut Ragfhib al-Ishfahani, millah berarti din sesuatu yang disyariatkan Allah bagi hambaNya melalui risalah yang dibawa oleh para nabi-Nya agar mereka dapat berkomunikasi atau berhubungan dengan Allah. Sementara menurut M. Quraish Shihab, kata millah sering dipersamakan dengan din, karena agama adalah tuntunan-tuntunan yang disampaikan Allah Swt. bagaikan sesuatu yang diimlakan atau ditulis, sehingga sama sepenuhnya dengan apa yang disampaikan itu. ${ }^{23}$

b. Din

Thabāthabā'i mengemukakan pengertian dìn dalam dua pengertian, yaitu pengertian umum dan luas dan pengertian khusus. Pengertian umum dan luas, Thabāthabā'i menggunakan tiga istilah, yaitu sunnah, thariqah, dan sabīl yang berlaku dalam suatu masyarakat. Dari pengertian ini, Thabāthabā'i menyatakan bahwa semua orang, baik ia beriman atau tidak atau bahkan yang tidak mengakui adanya Allah, pasti beragama. Karena setiap orang pasti mengikuti hukuk-hukum tertentu dalam perbuatannya, baik hukum itu disandarkan kepada wahyu maupun tidak, seperti kepada seseorang (tokoh) atau masyarakat. ${ }^{24}$

Adapun pengertian khusus dari din yaitu sunnah dan thariqah Ilähiyyah yang berlaku bagi semua manusia di dunia dengan tujuan untuk meraih kesempurnaan hidup di akhirat dan kehidupan abadi yang hakiki di sisi Allah. Dalam bahasa yang lain, Thābathabā'i mendefinisikan agama sebagai serangkaian perintah Tuhan tentang perbuatan dan akhlak, yang dibawa oleh para rasul, untuk menjadi pedoman bagi umat manusia. $^{25}$

\section{c. Syari'’ah}

\footnotetext{
${ }^{23}$ Waryono Abdul Ghafur, Persaudaraan Agama-agama, Millah Ibrahim dalam Tafsir Al-
} Mizan, (Cet. I, Bandung: PT. Mizan Pustaka, 2016), h. 42-43.

${ }^{24}$ Waryono Abdul Ghafur, Persaudaraan Agama-agama., h. 67.

${ }^{25}$ Waryono Abdul Ghafur, Persaudaraan Agama-agama., h. 67. 
Berbicara mengenai agama, tidak dapat dilepaskan dari uraian syari’ah. Istilah syari' ah merupakan kata jadian dari kata syara'ah yang berarti "air yang banyak" atau "jalan menuju sumber air". Jalan tersebut adalah jalan yang jelas. Pengertian itu kemudian dipinjam untuk menyebut jalan ketuhanan. Syarì'ah dinamakan demikian karena menyerupai jalan menuju air. Lebih jelasnya, agama dinamai syari 'ah karena ia adalah sumber kehidupan ruhani sebagaimana air yang menjadi sumber kehidupan jasmani. Tunt unan agama juga dapat berfungsi membersihkan kekotoran material. ${ }^{26}$

Dari pengertian itu, Thabāthabā'i menjelaskan bahwa syarì'ah adalah jalan terbentang untuk suatu umat tertentu dan nabi tertentu yang diutus untuk umat tertentu pula, seperti syari'ah Nūh, syari'ah Mūsa, syari'ah $\bar{I}_{s} \bar{a}$, dan syari'ah Muhammad. $^{27}$

Dengan demikian, menurut hemat peneliti makna millah, din, dan syari'ah merupakan tuntunan Ilāhi yang bersifat umum dan mencakup semua umat. Namun, din bersifat universal dan dapat mencakup sekian banyak syari'ah, sementara syari' $a h$ dan millah bersifat temporer. Oleh sebab itu, agama kembali kepada perannya sebagai oase spiritualitas dan moralitas di tengah kemanusiaan.

\section{Persepsi Siswa Terhadap Toleransi Antarumat Beragama}

1. Pemahaman dan Sikap Siswa terhadap Toleransi Antarumat Beragama

Pandangan berbeda, pemikiran berbeda adalah suatu kemajemukan dan keniscayaan. Karena sifat alamiah manusia yang berbeda-beda sesuai dengan Sunnatullah tersebut, maka sangat logis bahwa ajaran Allah tentang persaudaraan berdasarkan iman diberikan dalam rangka kemajemukan (pluralitas), bukan ketunggalan (monolitika). ${ }^{28}$ Ayat-ayat suci yang telah dikutip itu semuanya mencerminkan keadaan umat Islam yang plural atau majemuk sejak masa awal, yaitu masa Nabi sendiri. Pluralitas itu memang tidak menyangkut masalah-masalah asasi seperti keimanan dan ketakwaan, malainkan disebabkan oleh perbedaan latar belakang masing-masing pribadi dan kelompok kalangan umat itu sejak dari dahulu. Misalnya, tidak mungkin mengingkari adanya sisa-sisa primordial yang kurang baik seperti faktor keturunan, kesukuan, kedaerahan, dan sosial budaya lainnya. ${ }^{29}$ Secara spesifik kitab suci menyebutkan kepribadian Nabi yang penuh pengertian dan toleransi serta lapang dada, yaitu Firman Allah:

Dan dengan adanya rahmat dari Allah maka engkau (Muhammd) bersikap lunak (lemah lembut) kepada mereka. Seandainya engkau kasar dan keras hati, maka pastilah mereka akan menyingkir dari sekelilingmu. Karena itu maafkanlah mereka, mohon ampunan bagi mereka, dan bila engkau telah berketetapan hati,

\footnotetext{
${ }^{26}$ Waryono Abdul Ghafur, Persaudaraan Agama-agama., h. 71.

${ }^{27}$ Waryono Abdul Ghafur, Persaudaraan Agama-agama., h. 71-72.

${ }^{28}$ Nurcholis Majid, Masyarakat Religius, Membumikan Nilai-nilai Islam dalam Kehidupan (Cet. IV, Jakarta: PT. Dian Rakyat, 2010), h. 29.

${ }^{29}$ QS. Ali Imran: 159, Diterjemahkan oleh Nurcholis Majid, Masyarakat Religius, h. 32.
} 
maka bertawakkallah kepada Allah. Sesungguhnya Allah Cinta kepada orangorang yang bertawakkal. ${ }^{30}$

Dalam melakukan pengamatan dan wawancara di lokasi penelitian, peneliti menemukan pelbagai konsep persepsi yang dikotomis dan bervariasi. Secara rasional, peneliti berupaya menelisik lebih jelas tentang pemahaman siswa/siswi di sekolah tersebut. Sebelum peneliti membagikan angket kepada para informan/responden, peneliti melakukan wawancara secara lisan atau face to face. Terkait dengan pemahaman siswa terhadap toleransi antarumat beragama yakni sikap terbuka dengan semua agama tanpa ada batasan, ditemukan bahwa siswa/siswi masih sulit untuk membuka diri terhadap umat yang berbeda agama sebagai alasan akan memberikan sugesti yang buruk bagi keimanan mereka. Padahal untuk menghormati keyakinan orang lain dengan cara membuka diri adalah satu-satunya jalan agar kerukunan dan kedamaian tetap terjaga, sebagaimana firman Allah swt dalam QS. Al-Hajj/22: 40 di bawah ini:

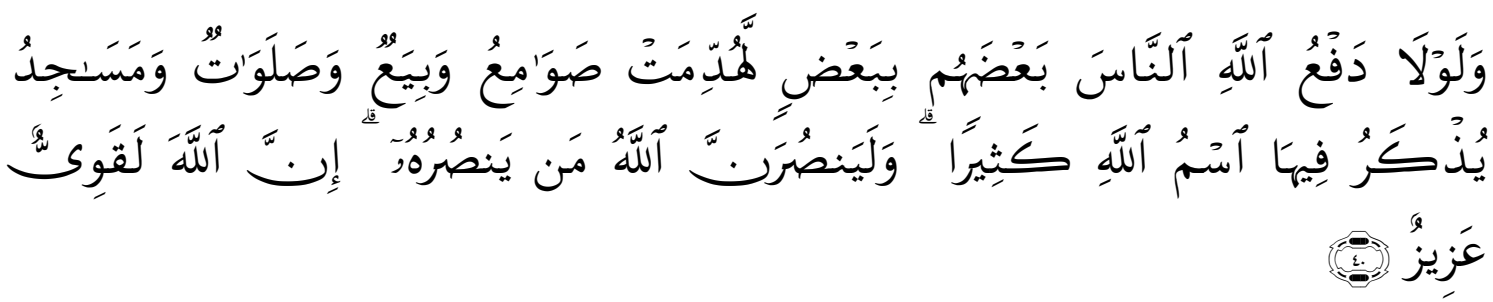

Terjemahnya :

Dan sekiranya Allah tidak menolak sebagian manusia dengan sebagian yang lain, tentulah telah dirobohkan biara-biara Nasrani, gereja-gereja, rumahrumah ibdadah orang Yahudi, dan masjid-masjid, yang di dalamnya banyak disebut nama Allah. ${ }^{39}$

Ayat di atas menjadi landasan untuk menerima sikap terbuka terhadap pemeluk agama lain, dan ayat tersebut juga memberikan alternatif kepada setiap umat agar mempunyai sikap saling mempercayai dan menghargai orang-orang non-Muslim. Menurut peneliti, Tuhan juga bertoleransi pada agama-agama lain selain Islam, dalam hal keselamatan mereka (non-Muslim) di dunia dan di akhirat. Namun, menurut siswa/siswi di sekolah tersebut bahwa, Orang non-Muslim yang melakukan kebaikan, mereka hanya mendapat balasan di dunia, dan tidak mendapat pahala di akhirat apalagi diselamatkan dari siksa Allah karena mereka tidak memeluk Islam. Oleh sebab itu mereka seluruhnya berada di neraka dan kekal di dalamnya.

Adanya pemahaman-pemahaman tersebut di atas, menurutnya hanya satu agama yang dapat menyelamatkan pemeluknya yakni Islam. Al- Qur'an telah

26.

\footnotetext{
${ }^{30}$ Nurcholis Majid, Masyarakat Religius, Membumikan Nilai-nilai Islam dalam Kehidupan, h.

${ }^{31}$ Kementerian Agama, Al-Qur'an dan Terjemahnya, h. 337.
} 
menunjukkan, seperti Firman Allah swt dalam QS. Al-Baqarah/2 :62 sebagai berikut:

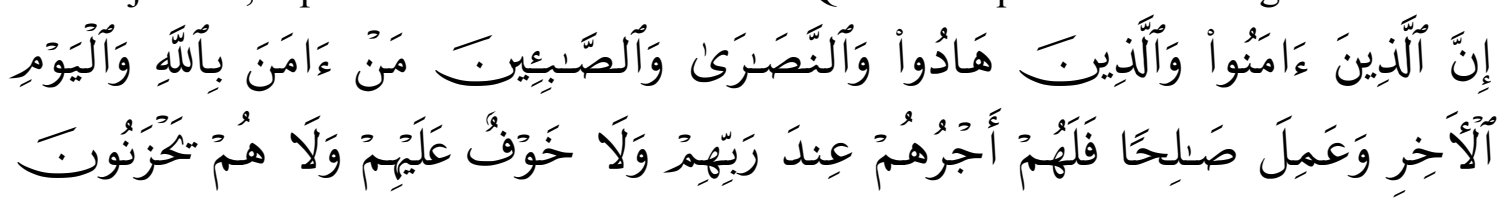

Terjemahnya:

Sesungguhnya orang-orang yang beriman, orang-orang Yahudi, orang-orang Nasrani dan orang-orang Shabi'in, siapa saja (di antara mereka) yang beriman kepada Allah dan Hari Akhir, dan melakukan kebajikan, mereka mendapat pahala dari Tuhan mereka, tidak ada rasa takut pada mereka, dan mereka tidak bersedih hati. ${ }^{32}$

Asbabun Nuzul ayat 62 di atas, As-Suddi ra menjelaskan, bahwa ayat ini diturunkan sehubungan dengan para sahabat Salman al-Farisi ra. Mereka masih memeluk agama Nasrani dan belum sempat memeluk agama yang dibawa Rasulullah saw. Mereka yang sungguh beriman kepada Allah dan Rasul-Nya, meski masih tetap memeluk agama semula, ibadah mereka tetap diterima dan mendapat pahala dari Allah swt. (Hadis Shahih, riwayat Ibnu Abi Hatim dan al-Adni). ${ }^{33}$

Ayat ini tidak berkata bahwa semua agama adalah benar. Ayat ini hanya mengatakan bahwa semua golongan agama akan selamat selama beriman kepada Tuhan Yang Esa, hari akhir dan beramal saleh. Tiga poin ini menjadi syarat mutlak untuk beroleh keselamatan dan pahala-Nya. Sungguh bijak bila kita berkata, "Semua agama adalah benar menurut keyakinan masing-masing." 34

Sebagai pelengkap pernyataan di atas Abdullah Yusuf Ali menjelaskan.

The Muslim position is clear. The Muslim does not claim to have a religion peculiar to himself. Islam is not a sect or on ethnic religion. In its view all religion is one, for Thuth is one. It was the religion preached by all the ealier prophets.

Artinya, all Relligions, semua Agama (dengan "A" besar) adalah satu karena sejatinya kebenaran tak pernah dua atau tiga, tapi Esa. ${ }^{35}$

Peneliti meyakini bahwa yang di sebut pemahaman terhadap toleransi antar umat beragama, yakni adanya sikap menerima keyakinan teologi dan pahaman agama lain serta membebaskan pengklaiman bahwa hanya satu agama yang selamat. Lantas Ridha dalam tafsirnya atas QS. 2: 26 secara halus mengutarakan deskripsi Ghazali menyoal non-Muslim yang tidak terjangkau risalah Islam (the reached), dalam hal ini Ridha memberi batasan antara orang yang terjangkau risalah Islam dan yang tidak,

\footnotetext{
${ }^{32}$ Kementerian Agama, AL-Qur'an dan Terjemahnya, h. 10.

${ }^{33}$ Kementerian Agama, AL-Qur'an dan Terjemahnya, Asbabun Nuzul dari Ayat, h. 10

${ }^{34}$ Fauz Noor, Berpikir seperti Nabi, Perjalanan menuju Kepasrahan, h. 160.

${ }^{35}$ Fauz Noor, Berpikir seperti Nabi, Perjalanan menuju Kepasrahan, h. 159.
} 
Tuhan memaafkan orang-orang yang tidak terjangkau risalah Islam. ${ }^{36}$ Dalam redaksi hadis, dikatakan bahwa "Tuhan mempunyai 100 Rahmat dan 1 Rahmat diturunkan di bumi untuk hamba-Nya, 99 Rahmat akan ditebarkan pada hari pembalasan amal-amal manusia". Jadi demikian dapat difikirkan dan di kontemplasikan teks hadis tersebut, satu rahmat saja sudah mendatangkan kebaikan bagi setiap umat, apalagi 99 rahmat yang tersisa. Bila demikan, mustahil kalau non-Muslim seluruhnya berada kekal di dalam neraka dan memeroleh siksaan.

Menurut analisa peneliti, maka non-Muslim yang tidak mendapat akses ke risalah akan dimaafkan, berbeda dengan Muslim maupun non-Muslim yang memeroleh akses tersebut namun menolak karena taklid buta dan tidak menggunakan akal untuk mencapai kebenaran absolut. Pembaca al-Qur'an sedapat mungkin mampu membebaskan pikiran manusia dari keterkungkungan dan kejumudan, serta mulai memandang aspek dimensi perspektif filosofis dan sosiologis al-Qur'an. Sikap toleransi yang dipahami siswa umumnya terbatas dalam persoalan keyakinan yang tidak boleh disamaratakan dengan agama-agama lainnya. Menurut mereka, aqidah akhlak dan fikih merupakan pelajaran inti bagi setiap orang yang belajar agama agar dapat memahami agamanya lebih intens dan terbebas dari pengaruh agama tertentu.

Sejarah Nabi saw yang begitu cerah dan gagasan cemerlang wihdah al-adyan yang ditawarkan para sufi untuk mengukuhkan eksistensi pluralisme agama telah "dikaburkan" oleh para fuqaha. Apalagi saat ini produk fikih justru yang paling laris dan digemari oleh mayoritas umat Muslim. Seakan Islam adalah agama fikih. Barangkali inilah yang menjadi sebab mengapa sebagian umat Muslim sulit menanamkan rasa toleransi, karena sepertinya mereka telah tertular virus intoleransi dan kebencian yang ditebarkan oleh nalar fikih. ${ }^{37}$ Harus diakui, adalah sulit untuk menumbuhkan sikap terbuka terhadap orang lain yang berbeda agama ketika sekilas pandang, seolah-olah mereka hendak menghancurkan keyakinan agama umat lain, sementara kita berpikir bahwa agama kitalah yang paling benar.

\section{E. Faktor-faktor yang Memengaruhi Rendahnya Persepsi Siswa terhadap Toleransi antarumat Beragama dan Upaya Optimalisasi Rekonstruksi Persepsi Siswa terhadap Toleransi antarumat Beragama}

Toleransi merupakan sikap yang adil dalam melihat perbedaan pemikiran dan pemahaman setiap umat. Dari segi penerapan merupakan perintah dan kewajiban Allah swt untuk setiap individu agar dapat saling menerima dan menghargai keyakinan orang lain. Allah swt telah memerintahkan setiap manusia untuk menjadi manusia yang "wasathan", dalam arti adil, umat pertengahan, atau tidak timpang dalam memandang semua ajaran Islam, bertipikal moderasi, baik ajaran tentang Tuhan atau akidah yang diajarkan. Dengan demikian akan dapat hidup damai tanpa perpecahan antar agama, firqah maupun mazhab lain. Namun dalam penerapannya yang terjadi di sekolah

\footnotetext{
${ }^{36}$ Mohammad Hasan Khalil, Islam dan Keselamatan Pemeluk Agama Lain, h. 210.

${ }^{37}$ Mukti Ali, Islam Mazhab Cinta, h. 352.
} 
tersebut belum efektif serta mengalami banyak hambatan. Adapun faktor-faktor yang memengaruhi persepsi siswa terhadap toleransi ialah:

1. Kekeliruan Pendidikan Menyikapi Perbedaan

Adanya penolakan terhadap pendidikan falsafah dan tasawuf di sekolah semi pesantren tersebut, padahal ini penting untuk diajarkan kepada siswa-siswi meskipun secara implisit, agar dapat mencerap ajaran-ajaran agama dengan baik. Hal ini merupakan problem yang utama untuk pemahaman siswa dalam menyikapi perbedaan. Lebih lanjut peneliti temukan, biasanya pada waktu pagi atau siang hari siswa-siswi berhalaqah di masjid dan memulai metode hafalan al-Qur'an/hadis serta dibimbing dan didampingi langsung oleh guru mereka. Namun, selesai menghafal siswa/siswi tidak diberikan penjelasan secara kontekstual ayat-ayat yang dihafal tersebut, sehingga terkesan memberi pemahaman yang bersifat tekstual. Hal ini merupakan kekeliruan guru dalam menggunakan konsep pendidikan yang secara kualitas penerapannya belum maksimal. Kekeliruan guru dalam mengajar biasa dipengaruhi oleh kurang disiplin untuk mencari tahu kekurangan metode atau bahan ajar serta minimnya pemahaman untuk mempelajari ilmu agama secara kontekstual-komprehensif, bila dipahami konsep tersebut merupakan role model dalam pengajaran akhlak. Menurut Ibnu Khaldun, di antara faktor yang tidak memberi pengaruh dalam pengajaran adalah apabila guru menggunakan catatan atau buku ringkasan, dan terlebih lagi para peserta didik diberi tanggung jawab untuk menghafal teks dahulu, kemudian diikuti dengan penjelasan secara terperinci, sehingga tidak keliru dalam memahami teks-teks agama dan tidak terkesan tekstualis.

Lebih lanjut, bila dipahami secara intens, ternyata ditemukan adanya integritas antara nilai ke-islaman dan falsafah dalam dunia pendidikan, namun sayangnya di sekolah tersebut memarjinalkan nilai-nilai filsafat dan tasawuf. Menurut Imam Malik, "orang yang berfikih tanpa bertasawuf maka ia zindik, dan orang yang bertasawuf tanpa berfikih maka ia fasik". Artinya peserta didik perlu pemahaman keagamaan yang kritis dan irfani.

Menurut Fazlur Rahman, dunia pendidikan Islam pada akhir-akhir ini mengalami tidak relevan dengan tuntutan perkembangan zaman, bersifat stagnan kurang merespons perkembangan sosial yang begitu cepat berubah. Jika umat Islam ingin dapat menjadi rahmatan bagi alam semesta, maka hendaknya ia mempunyai kreativitas berpikir tinggi, dengan kebebasannya, maka subjek didik sebagai manusia yang mempunyai kebebasan tidak akan pernah kehilangan arah dalam menghadapi berbagai kemelut dalam kehidupannya. Manusia tampil sebagai ego yang bebas merekayasa alam semesta dengan tidak menafikkan aspek transendental, Tuhan, sebagai ego terakhir. ${ }^{38}$

\footnotetext{
${ }^{38}$ Abd. Rachman Assegaf, Aliran Pemikiran Pendidikan Islam, Hadharah Keilmuan Tokoh Klasik Sampai Modern (Cet. I, Jakarta: PT. RajaGrafindo Persada, 2013), h. 220-221.
} 
Fazlur Rahman menginginkan pendidikan hendaknya mengembangkan sifat kritis dan kreatif, sehingga diharapkan kaum Muslim berfikiran bebas. Ia mengkritik metode hafalan yang marak sampai saat ini karena kekurangan literatur. Sehingga hal ini akan menimbulkan kemerosotan secara gradual standar-standar pendidikan. Menurutnya, pengetahuan adalah sesuatu yang harus dicari dan ditemukan oleh pikiran yang memegang peranan aktif di dalamnya, jadi sifat menerima/taklid buta dan pasif seharusnya dihilangkan.

\section{Sekat Terhadap Ilmu Pengetahuan}

Islam pada dasarnya tidak pernah mempertentangkan antara satu macam pengetahuan dengan pengetahuan lainnya. Begitu juga Islam tidak memperhadapkan satu macam pendekatan keilmuan berikut aneka ragam pengetahuan yang dihasilkannya. Penerimaan Islam terhadap pelbagai macam pendekatan keilmuan dan hasil-hasilnya sekaligus, karena Islam memandang, bahwa semua pengetahuan berasal dari Allah. ${ }^{39}$

Seorang guru/pendidik setidaknya memahami tujuan dari belajar dan mengajar, terkait masalah pendidikan dapat dikemukakan di sini bahwa guru perlu senantiasa menambah ilmu pengetahuan. ${ }^{40}$ Seorang guru hendaklah menerima segala bentuk pandangan keilmuan/pengetahuan tanpa harus memberi ruang sekat dalam menerima ilmu pengetahuan, bila ini terjadi justru akan menjadikan guru pasif dan kaku dalam menyampaikan pembelajaran kepada siswa. Implikasinya akan terlihat kepada pemahaman siswa dalam menerapkan pengetahuan tersebut, karena kurangnya literatur dan rendahnya minat untuk menerima pelbagai sumber hasanah pengetahuan.

Menurut Ibnu Khaldun, bahwa tidak cukup bagi seorang guru untuk melengkapkan diri dengan ilmu saja, sebagai pengetahuan yang harus disediakan oleh guru kepada siswa. Beliau menyarankan, agar kita dapat memperbaiki cara menyampaikan ilmu kepada golongan muda atau kanak-kanak. ${ }^{41}$ Memperbaiki metode penyampaian yang dimaksud hendaknya seorang guru menghilangkan kejumudan dan menjauhi sikap eksklusif dalam mengolah pengetahuan. Jika hal ini dilakukan seorang pendidik maka setidaknya ia tidak membuat para siswa berada dalam ketimpangan pengetahuan akibat eksklusivisme dan fanatisme pengetahuan.

\section{Perspektif yang Berbeda}

Berdasarkan perbedaan prinsip-prinsip keberagaman adat, kebiasaan dan budaya, sebagian siswa mempertimbangkan bahwa toleransi dapat dilihat dari faktor agama, adat/kebiasaan, dan budaya, misalnya, pikiran untuk tidak mentolerir habit atau kebiasaan para golongan non-Muslim karena akan berimplikasi pada rusaknya keimanan atau pemberian sugesti yang buruk dari mereka. Jika hal ini dijadikan suatu problem dalam bertoleransi, maka akan memberi ruang untuk bersikap intoleran.

\footnotetext{
${ }^{39}$ Munir Che Anam, Muhammad \& Karl Marx, h. 43-44.

${ }^{40}$ Beberapa pemikiran Ibnu Khaldun terkait masalah pendidikan (Lihat: Aliran Pemikiran Pendidikan Islam h. 132).

${ }^{41}$ Abd. Rachman Assegaf, Aliran Pemikiran Pendidikan Islam, h. 132.
} 
Sebagai contoh, misalnya terdapat beberapa orang siswa menerima dengan siapa saja umat untuk bertoleransi dan menghargai perbedaan, namun tidak ingin toleran dengan umat Nasrani dan Yahudi karena orang-orang Nasrani dan Yahudi adalah kasar dan tempramental. Sikap menstigmatisasi orang lain inilah yang akan menimbulkan intoleransi dan perpecahan karena memandang dari faktor agama, adat, dan kebiasaan.

Telah dikatakan pandangan keagamaan yang jelas keliru dan bernada ekstrem seperti itu kemudian terkikis habis oleh sejarah, sehingga tidak tersisa lagi sekarang ini selain catatan-catatan heresiography. Betapa agama yang benar dan hanif itu dapat saja dipahami secara menyimpang jauh karena berbagai hal yang bersifat biografis pribadi bersangkutan, latar belakang sosial dan budaya, dan lain-lain. ${ }^{42}$ Kebencian sektarian yang berkembang dalam tradisi suatu agama sering dikutip untuk membuktikan bahwa "agama" secara kronis intoleran, akibatnya tradisi-tradisi agama ini sering menyimpang dan mengembangkan ciri agresif. ${ }^{43}$ Disinilah letak kesulitan mengambil sikap toleran dalam hubungan antaragama maupun kelompok karena lebih cenderung disebabkan oleh pemahaman dan sikap dalam melihat atau ditemukannya perbedaan turats, budaya, adat serta agama.

\section{Media sosial}

Umat dewasa ini hidup di tengah-tengah zaman era digital seperti handphone, tablet, computer dan lain sebagainya. Kecanggian teknologi sedikit banyaknya akan memengaruhi cara pandang serta cara pikir seseorang yang sering terkontaminasi dengan benda-benda tesebut, baik yang diterima dampak positif maupun negatif. Media sosial merupakan salah satu faktor yang memengaruhi pemahaman dan sikap keberagamaan masyarakat sosial khususnya di kalangan terdidik (pelajar/peserta didik). Perangkat media sosial seperti facebook, whatsApp, youtube, instagram, dan lain sebagainya sering digunakan oleh masyarakat hari ini baik itu di kalangan anak remaja, dewasa bahkan sampai di kalangan orang tua. Namun, perangkat media sosial yang sering digunakan oleh kebanyakan orang khususnya remaja/peserta didik adalah facebook dan youtube, secara kuantitatif perangkat tersebut tidak sedikit menyebarkan video, gambar-gambar atau berita-berita yang dianggap terjamin validitasnya (bukan hoax). Dengan mewabahnya pengaruh media sosial dapat memantik penggunanya untuk bersikap yang dapat saja mengabaikan nilai-nilai moral dan agama.

Hal-hal di atas sering merupakan pangkal terjadinya sikap intoleransi berdasar pandangan keagamaan, pandangan adat istiadat maupun pandangan politik yang berbeda. Penerimaan informasi baik bersifat tulisan maupun visual (tontonan) menjadi sebab timbulnya perpecahan, karena masyarakat termasuk anak didik disuguhkan bacaan atau tontonan yang berupa ancaman dan terkesan menakut-nakuti, hal ini berdampak kepada gejala sosial beragama yang tidak sehat. Bahaya kelengahan

\footnotetext{
${ }^{42}$ Nurcholis Madjid, Masyarakat Religius, Membumikan Nilai-nilai Islam dalam Kehidupan, h. 37.

${ }^{43}$ Karen Amstrong, Fields of Blood, h. 518.
} 
dalam menghadapi itu semua adalah jika terpedaya dan tidak cerdas dalam menggunakan media sosial dapat mengancam persatuan dan kesatuan umat beragama. Dengan mempertimbangkan pelbagai penerimaan informasi memadai, ketentuan keagamaan dapat dipertimbangkan untuk menetapkan sikap dan melakukan tindakantindakan yang sewajarnnya. Dalam hubungannya dengan suatu pandangan keagamaan, terikat dengan apa yang diyakini sebagai benar, setelah ia sendiri melakukan tabayyun/ijtihad dengan menggunakan bahan dan perangkat yang tersedia di hadapannya untuk digunakan dengan baik dan bijak tanpa kehilangan kesadaran akan kenisbian hasil ijtihadnya itu. Dengan demikian hal ini akan meminimalisir sedikit demi sedikit ekstremisme di dunia pendidikan khususnya di lingkungan sekolah siswa SMP Unismuh Makassar.

Untuk meminimalisir dan memfilterasi faktor yang menghambat persepsi siswa terhadap toleransi, antara lain:

1. Peran Orang Tua

Meskipun peneliti tidak melakukan penelitian terhadap orang tua siswa, namun peneliti melakukan interview secara lisan dan tulisan kepada para siswa tentang keberagamaan di lingkungan keluarga mereka, misalnya dengan cara mengambil sampel latar belakang pendidikan, pekerjaan orang tua dan lain sebagainya. Peran orang tua merupakan solusi tepat dalam melakukan rekonstruksi persepsi siswa terhadap toleransi antarumat beragama. Untuk memberikan pemahaman agama yang baik kepada anak didik hendaknya orang tua menumbuhkembangkan pribadi anak yang diliputi dengan nilai-nilai Islam yang benar, karena tujuan pendidikan bagi anak untuk mengembangkan kekuatan akhlak yang akan menimbulkan rasa kasih kepada semua umat, baik Muslim maupun non-Muslim. Dalam hal ini sebagaimana prinsip Nabi saw, "Cinta adalah agama (asas)ku."

Anak didik perlu dipantau dan dibimbing dari waktu ke waktu, pada saat mereka di rumah ibu-bapaknya menjadi pembimbing, sebab orang tua adalah pendidik utama bagi anak-anaknya. Dalam mendidik anak hendaknya diperlukan metode yang baik. Menurut al-Ghazali, metode mendidik anak adalah sangat penting karena anak adalah amanat bagi orang tuanya, dan karena itu orang tua bertanggung jawab atas pendidikan anak-anaknya. Jika anak-anak dibiasakan dalam hal-hal yang baik dan diajarkan dengan cara yang baik pula, maka mereka akan tumbuh dalam kebaikan dan akan memperoleh kebahagiaan di dunia dan di akhirat nanti. Sedangkan orang tua dan para guru akan memperoleh bagian pahalanya di akhirat nanti. Sebaliknya, kalau anak dibiasakan dengan kejahatan dan diabaikan seperti layaknya hewan buas, maka mereka akan sengsara dan merugi, sedangkan beban dosanya akan dipikulkan di atas pundak orang tua dan guru yang bertanggung jawab terhadapnya. Kalau ayah dipandang sebagai perisai terhadap api di dunia, maka alangkah lebih bermaknanya jika ia menjadi perisai bagi anaknya terhadap api neraka di akhirat. Al-Ghazali memandang bahwa tujuan pendidikan adalah untuk menjamin masa depan anak di akhirat ( $q \bar{u}$ 
anfusākum wa ahlikum nāran). Masa kanak-kanak amat penting karena pada asalnya jiwa anak adalah murni dan terbuka terhadap pengaruh. Karakternya tertulis di atasnya sebagaimana pena di atas kertas putih. Masa depannya ditentukan oleh pendidikan dan pendidiknya. $^{44}$

Kita melihat, sebahagian peran orang tua dalam pendidikan keluarga telah kehilangan konsep pendidikan yang benar. Terkadang dijumpai orang tua yang acuh kepada pemahaman anak didiknya, apalagi yang berhubungan dengan agama. Adapun orang tua yang mengajarkan anak-anak mereka tentang agama, namun memberikan nilai-nilai atau ajaran-ajaran sebagai agama pembenci, ekstrem atau bahkan intoleran. Terdapat perbedaan yang tak terelakkan didasarkan pada pemahaman yang sempit dan kondisi tempat tinggal. Hal ini membuat anak didik akan mendapat pendidikan agama yang kurang mumpuni. Sebagai akibat anak didik bersikap tidak bijaksana dalam menyikapi perbedaan.

Demikian juga menyangkut hubungan dengan para penganut agama-agama lain. Sikap mayoritas umat Muslim, dalam melestarikan keimanan, umumnya tidak cukup disertai rasa kemanusiaan terhadap orang-orang berbeda agama dengan mereka. Mereka, selain tidak merasa tergugah untuk menemukan 'kelapangan' di dalam ranah keimanan yang sangat tertutup, tidak mampu menangkap kemurahan dan kasih sayang Tuhan. Mereka juga tidak dapat memahami pluralisme eksternal sehingga keliru dalam memahami para penganut agama lain, untuk melakukan diskusi atau dialog sebagai bukti bahwa mereka benar dan para penganut agama-agama lain salah. Tak mengherankan bila kedamaian hanya menjadi 'hiburan' di alam mimpi. ${ }^{45}$

Disini perlunya orang tua berperan penting dalam pendidikan anak-anak mereka, apalagi orang tua yang berpendidikan sekiranya tidak bersikap tertutup terhadap khazanah pengetahuan, perlunya belajar dan memahami filsafat dan tasawuf, sudah sepantasnya kita tidak lupa untuk mempelajari ilmu yang dewasa ini sudah hampir punah ini. Dengan mempelajari filsafat, sekiranya kita diajarkan untuk cinta terhadap kebijaksanaan yang akan berimplikasi kepada bijak dalam beragama, bijak dalam melihat perbedaan, serta bijak dalam menilai umat lain.

\section{Peran Tenaga Pendidik}

Posisi guru bukan hanya sebagai panggilan moral untuk mengajar, namun juga memiliki tanggung jawab untuk membentuk akhlak para siswa dan juga harus mempunyai totalitas semangat memperkaya wawasan keislaman. Guru harus mampu menyadarkan diri akan kewajibannya dalam memberi pemahaman yang baik dan tersistematis. Demi mewujudkan siswa yang berakhlak dan toleran, seorang guru seharusnya tidak memandang remeh disiplin keilmuan lainnya, misal guru yang pakar dalam ilmu fikih, tidak memandang remeh ilmu filsafat/tasawuf. Dan demikian pula sebaliknya. Sebab sikap meremehkan adalah akhlak yang tercela bagi guru. Dengan

\footnotetext{
${ }^{44}$ Abd. Rachman Assegaf, Aliran Pemikiran Pendidikan Islam, h. 113-114.

${ }^{45}$ Mukti Ali, Islam Mazhab Cinta, h. 36.
} 
demikian, sudah seharusnya apabila guru memberi kelonggaran kepada peserta didiknya untuk menekuni disiplin ilmu lain yang tidak ia ajarkan.

Seperti Rumi berkata:

"Allah telah mengajarkan semua ilmu pengetahuan, jadi kenapa mengkhususkan pada pengajaran al-Qur' an saja? Allah yang telah menciptakan langit dan bumi [QS. al-An'am: 1], lantas kenapa harus mengkhususkan hanya pada langit dan bumi, bukankah Allah yang telah menciptakan semua yang ada di dunia ini?."46

Dengan cara seperti ini, siswa atau peserta didik akan memeroleh wawasan yang luas, karena dengan wawasan keilmuan yang luas akan membuat para siswa tidak mudah terprovokasi dan eksklusif dari berbagai peristiwa yang ia hadapi di lingkungan sekitarnya. Manusia adalah makhluk yang berakal. Akal tersebut melakukan aktivitasnya yang sering kita sebut dengan berpikir. Jika akal mempunyai substansi spiritual, maka dalam berpikir juga mempunyai kekuatan spiritual. Ibn Khaldun mengatakan, bahwa sesungguhnya ilmu dan berpikir terjadi dengan sebab adanya kekuatan tertentu dalam diri manusia. Lantaran adanya ilmu dan berpikir itulah, maka dapat mengembangkan akal seseorang. ${ }^{47}$ Demikian itu, apabila akal seseorang mulai berkembang, maka akan memeroleh wawasan yang luas dan terhindar dari sikap fanatik yang berlebihan.

Seperti diketahui, persepsi manusia tentang Tuhan bisa sangat tidak seimbang (tidak utuh), karena persepsi itu biasanya amat terpengaruh oleh pengalaman hidup manusia itu sendiri. Oleh sebab itu, tenaga pendidik/guru harus menanamkan nilai-nilai tasawuf dalam diri peserta didik seperti cinta kasih kepada sesama, pemaaf, menahan amarah, toleran, ramah dan sebagainya.

Lembaga-lembaga pendidikan kita saat ini umumnya didominasi oleh orientasi lahiriah Fiqh dan Kalam, yakni oleh segi-segi eksoteris. Karena didominasi Fiqh, seorang anak didik lebih paham, misalnya, syarat dan rukun bagi sah tidaknya salat, tampak dengan mantap mengetahui apa sesungguhnya makna salat itu bagi pembentukan diri pribadinya, lahir dan batin, dan karena didominasi Kalam. Ia lebih mampu, misalnya, bagaimana membuktikan bahwa Tuhan ada, tanpa memiliki keinsafan yang cukup mendalam tentang apa makna kehadiran Tuhan (rasa Ketuhanan dalam kalbu) itu dalam hidup ini. ${ }^{48}$

Maka persoalan pertama ialah tidak hanya orang tua peserta didik, tenaga pengajar itu sendiri yang harus memperkenalkan makna pengajaran tasawuf kepada peserta didik. Dengan cara menyadarkan para anak didik akan makna-makna ibadah lahiriah hingga mereka dapat memahami pentingnya ibadah batiniah. Pendidikan keluarga dan pendidikan di sekolah serta kemampuan pengajar sangat menentukan akhlak peserta didik.

\footnotetext{
${ }^{46}$ Jalaluddin Rumi, Fihi Ma Fihi, terj. Abdul Latif, Fihi Ma Fihi: Mengarungi Samudera Kebijaksanaan, (Yogyakarta: Grup Relasi Inti Media,anggota IKAPI, 2017). H. 345-346.

${ }^{47}$ Abd. Rachman Assegaf, Aliran Pemikiran Pendidikan Islam, h. 174

${ }^{48}$ Nurcholis Madjid, Masyarakat Religius, h. 107.
} 


\section{Peran Mubaligh}

Menyadarkan masyarakat tentang pentingnya sikap toleransi yang diteladani oleh Nabi saw. Peran mubaligh sangat urgen untuk memberi pemahaman agama yang baik dan benar. Penyampaian dakwah yang baik atau keliru di lingkungan masyarakat akan berdampak memengaruhi lingkungan keluarga, kemudian ke anak didik. Sebagaimana hasil wawancara yang dilakukan bersama kepala sekolah H. Irwan Akib "Para ulama atau mubaligh sangat berperan penting dalam memberikan pemahaman agama yang baik, dan dalam menyampaikan dakwah hendaknya harus mempunyai metode dakwah agar penerima dakwah tidak keliru memahami konsep dakwah. Pemahaman yang sempit akan membuat umat terpecah belah."49

Demi mewujudkan kehidupan bertoleransi diperlukan upaya untuk menjaga persatuan dan kesatuan dari masing-masing umat, dengan cara para mubaligh harus lembut dalam berucap dan sebisa mungkin menghindari pesan-pesan atau kalimatkalimat provokasi yang akan membuat umat bersikap radikal dan intoleran. Sebagaimana Rumi berkata dalam sajak-sajaknya:

"Dunia ini seperti gunung, apapun yang kamu katakan, entah itu baik atau buruk, akan didengarnya. Kalau kamu beranggapan, 'Aku sudah berkata baik', tapi gunung itu menganggapnya jelek,' maka sesungguhnya itu mustahil. Ketika burung Bulbul bernyanyi di pegunungan, mungkinkah nyanyiannya akan terdengar seperti suara gagak, suara manusia, atau suara keledai? Jika demikian, yakinlah bahwa saat itu kamu telah bersuara seperti keledai. Perbaguslah suaramu saat kamu melintasi gunung, kenapa kamu berbicara seperti suara keledai di depan gunung? Langit yang biru akan mempermanis gema suaramu. ${ }^{50}$

Dasar hukum mengenai adab berbicara adalah firman Allah dalam QS Lukman/12: 19 sebagai berikut:

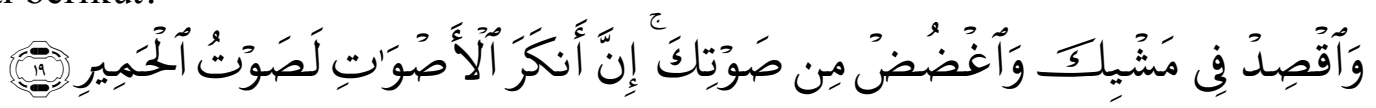

Terjemahnya:

Dan sederhanalah kamu dalam berjalan dan lunakkanlah suaramu. Sesungguhnya seburuk-buruk suara ialah suara keledai. ${ }^{51}$

Oleh sebab itu, keberadaan mubaligh sangat berpengaruh terhadap umat yang akan melahirkan beraneka ragam persepsi dalam beragama. Terbentuknya sikap atau pandangan beragama yang berbeda adalah tanggung jawab setiap mubaligh dalam menyampaikan dakwahnya.

4. Peran Masyarakat

\footnotetext{
${ }^{49}$ H. Irwan Akib. M.Pd, Kepala Sekolah, Wawancara, SMP Unismuh Makassar, 18 Januari, 2018.

${ }^{50}$ Jalaluddin Rumi, Fihi Ma Fihi, terj. Abdul Latif, Fihi Ma Fihi: Mengarungi Samudera Kebijaksanaan, h. 343-344.

${ }^{51}$ Kementerian Agama, Al-Qur'an dan Terjemahnya, h.
} 
Dalam menyadarkan kembali persepsi atau pemahaman keagamaan dengan baik dan bijaksana, maka diperlukan peran masyarakat yakni tokoh-tokoh yang dituakan di lingkungan masyarakat tersebut dengan cara memberi sumbangan dalam kegiatan sosial keagamaan dan berpartisipasi pada organisasi masyarakat yang akan bertanggung jawab dalam mengatur dan mengurus kedatangan para pemuka agama di lingkungan masyarakat, dengan cara melakukan filterasi terhadap tokoh-tokoh agama yang dianggap ekterem dalam beragama. Hal ini dapat meminimalisir sikap atau pemahaman yang intoleran. Hubungan toleran sesama manusia sangat dibutuhkan dalam kehidupan bermasyarakat, oleh sebab itu dengan adanya peran/organisasi di dalam masyarakat dapat juga membantu warga masyarakat untuk mendatangkan para pemuka agama dan saling berdialog antar lintas agama. Karena dengan begitu dapat memberi pemahaman dan mengajarkan seluruh masyarakat agar menjadi manusia yang berkepribadian damai dan toleran.

\section{PENUTUP}

\section{A. Kesimpulan}

Toleransi merupakan sikap manusia sebagai umat yang beragama dan mempunyai keyakinan untuk menghormati dan menghargai pandangan keagamaan manusia yang beragama lain. Untuk mewujudkan sikap toleran diperlukan pemahaman agama yang baik pula, dan disini diperlukan peran orang tua, guru, dan peran mubaligh dalam menyampaikan nasihat dan dakwah yang sesuai dengan teksteks keagamaan secara kontekstual. Sehingga masyarakat, khususnya para anak didik dapat menjalankan agamanya secara benar, damai, dan toleran.

Akhirnya, penelitian ini diharapkan bisa menjadi kritik, saran, serta usulan kepada berbagai pihak yang terlibat dalam pendidikan agama peserta didik, terutama untuk langkah-langkah rekonstruksi/membangun kembali pemahaman dan sikap yang terkait dengan pendidikan keagamaan serta pembentukan pemahaman yang bersifat inklusif-kontekstual di lingkungan keluarga, sekolah, dan masyarakat agar dapat menghormati dan menghargai keberagaman, serta tidak diskriminatif pada umat tertentu sebagai upaya persamaan hak dan nilai-nilai pancasila.

\section{DAFTAR PUSTAKA}

Al-Qur'an dan Terjemahnya

Ali, Mukti. Islam Mazhab Cinta. Bandung: PT. Mizan Pustaka, 2015.

Al-Munawar, Said Aqil Husin. Fiqih Hubungan Antar Agama. Jakarta: Ciputat Press, 2005.

Anam Che, Munir. Muhammad SAW \& Karl Marx, Tentang Masyarakat Tanpa Kelas, Cet. I, Yogyakarta: Pustaka Pelajar, 2008. 
Armstrong, Karen. Fields Of Blood, Mengurai Sejarah Hubungan Agama dan Kekerasan, Penterjemah Yuliani Liputo, Mizan Pustaka, 2017.

Assegaf, Abd Rachman. Aliran Pemikiran Pendidikan Islam. Jakarta: Raja Grafindo Persada, 2013.

Hasyim, Umar. Toleransi dan Kemerdekaan Beragama dalam Islam Sebagai Dasar Menuju Dialog dan Kerukunan Antar Agama. Surabaya: Bina Ilmu, 1979.

Gassing, H. A. Qadir dan Wahyuddin Halim. Pedoman Penulisan Karya Tulis Ilmiah. Makassar: Alauddin Press 2008.

Ghafur Abdul, Waryono. Persaudaraan Agama-agama, Millah Ibrahim dalam Tafsir AlMizan. Bandung: PT. Mizan Pustaka, 2016.

Gulo, W. Metode Penelitian. Jakarta: Grasindo, 2007.

Hasyim, Umar. Toleransi dan Kemerdekaan Beragama dalam Islam Sebagai Dasar Menuju Dialog dan Kerukunan Antar Agama. Surabaya:Bina Ilmu, 1979.

Hidayatullah, Syarif. Islam, Isme-isme Aliran dan Paham Islam di Indonesia. Yogyakarta: Pustaka Pelajar, 2010.

Madjid, Nurcholis. Islam Doktrin dan Peradaban. Jakarta: Paramadina, 2008. , Masyarakat Religius, Membumikan Nilai-nilai Islam dalam Kehidupan. Jakarta: Dian Rakyat, 2010.

Masduqi, Irwan, Berislam Secara Toleran, Teologi Kerukunan Umat Beragama, Cet. I, Bandung: Mizan Pustaka, 2011.

Mubarok, Achmad. Psikologi Dakwah. Jakarta: Pustaka Firdaus, 2001.

Noor, Fauz. Berpikir Seperti Nabi, Perjalanan Menuju Kepasrahan. Yogyakarta: Pustaka Sastra LKiS. 2009.

Rahman, Fazlur. Islam, Sejarah Pemikiran dan Peradaban, Penterjemah M. Irsyad Rafsadie, Mizan Pustaka, 2017.

Rumi, Jalaluddin. Fihi Ma Fihi, Mengarungi Samudera Kebijaksanaan, Penterjemah Abdul Latif, Grup Relasi Inti Media, 2017.

Shihab, M, Quraish. Wawasan Al-Qur'an; Tafsir Maudhlui Atas Berbagai Persoalan Umat. Bandung: Mizan Pustaka, 2007.

http://www.uin-suka.ac.id/berita/dberita/605.

https://kbbi.web.id/persepsi.html 